\title{
Protistan Skeletons: A Geologic History of Evolution and Constraint
}

\section{Citation}

Knoll, Andrew H., and Benjamin Kotrc. 2015. “Protistan Skeletons: A Geologic History of Evolution and Constraint." In Evolution of Lightweight Structures, ed. Christian Hamm: 1-16. doi:10.1007/978-94-017-9398-8_1.

\section{Published Version}

doi:10.1007/978-94-017-9398-8_1

\section{Permanent link}

http://nrs.harvard.edu/urn-3:HUL.InstRepos:30403697

\section{Terms of Use}

This article was downloaded from Harvard University's DASH repository, and is made available under the terms and conditions applicable to Open Access Policy Articles, as set forth at http:// nrs.harvard.edu/urn-3:HUL.InstRepos:dash.current.terms-of-use\#OAP

\section{Share Your Story}

The Harvard community has made this article openly available.

Please share how this access benefits you. Submit a story.

Accessibility 


\title{
Chapter 1
}

\section{Protistan Skeletons: A Geologic History of Evolution and Constraint}

\author{
Andrew H. Knoll and Benjamin Kotrc \\ Department of Earth and Planetary Sciences \\ Harvard University \\ Cambridge MA 02138, USA
}

\begin{abstract}
The tests and scales formed by protists may be the epitome of lightweight bioconstructions in nature. Skeletal biomineralization is widespread among eukaryotes, but both predominant mineralogy and stratigraphic history differ between macroscopic and microscopic organisms. Among animals and macroscopic algae, calcium minerals, especially carbonates, predominate in skeleton formation, with most innovations in skeletal biomineralization concentrated in and around the Cambrian Period. In contrast, amorphous silica is widely used in protistan skeletons, and a majority of the geologically recorded origins of silica biomineralization took place in the Mesozoic and early Cenozoic eras. Amorphous silica may be favored in protist biomineralization because of the material properties of both silica itself and the organic molecules that template its precipitation. The predominace of carbonates and phosphates in macroscopic skeletons may, in turn, reflect the low quantities of dissolved silica in fresh and marine waters. The evolutionary success of diatoms has depleted silica levels in surficial waters since the Cretaceous Period, and fossils show that other biological participants in the silica cycle have responded both through altered habitat preferences and reduced use of silica in test construction. These natural instances of doing more with less might serve to inspire continuing innovations in biomimetic design.
\end{abstract}




\subsection{Introduction}

The ninth century Persian polymath, Abu-Bakr Muhammed ibn Zakariya al-Razi first divided the material world into the categories of animal, vegetable and mineral (Strathern 2005). Although this classification would guide alchemists well into the Age of Enlightenment, even cursory inspection shows that the world is not so simple. Many animals and plants precipitate minerals, as do a broad array of microorganisms whose existence could not have been known to al-Razi. Bacterial metabolism induces the precipitation of carbonates, sulfides and oxides from pore waters in sediments (Konhauser and Riding 2012), and at least a few bacteria precipitate magnetite within their cytoplasm to guide movement (Frankel et al. 1998). Eukaryotic organisms precipitate a variety of minerals intracellularly, serving a range of functions that includes the regulation of buoyancy, gravity sensing, magnetotaxis, and storage (Raven and Knoll 2010). Of particular interest are those eukaryotes, large and small, that precipitate mineralized skeletons: tests, scales, spicules, sclerites, shells and bones.

More than fifty biominerals have been recorded in eukaryotic organisms, half of them containing calcium and a quarter crystallographically amorphous (Weiner and Dove 2003). Overwhelmingly, however, the minerals found in skeletons are Ca-phosphates (especially dahllite), calcium carbonate (calcite and aragonite), or amorphous silica. How are skeletal biominerals distributed among organisms, and what features of function and environment account for this distribution? How, as well, have biomineralizing eukaryotes evolved through time?

\subsection{The Phylogenetic Distribution of Biomineralized Skeletons}

Molecular research has begun to resolve evolutionary relationships among eukaryotic organisms. Most treatments recognize half a dozen "superkingdoms" within the Eukarya, although branching relationships among these major clades remain a topic of debate (e.g., Burki et al. 2008; Parfrey et al. 2010; Walker et al. 2011; Figure 1). Our understanding of skeletal biomineralization derives principally from animals, giving the impression that calcium carbonate 
is the most widespread means of mineralizing skeletal elements. Calcite and/or aragonite strengthen external skeletons in a number of phyla including the sponges, cnidarians, brachiopods, bryozoans, molluscs, annelid worms, and arthropods (e.g., Knoll 2003; Cuif et al. 2011, Wallace et al. 2012). Echinoderms also precipitate skeletal plates of calcite, but do so internally, beneath a thin layer of epidermis, and tunicates, as well, precipitate aragonitic spicules within their bodies. Among living animals, phosphatic skeletons are formed externally by some brachiopods, internally by vertebrates and, rarely, as minor components of arthropod exoskeletons (Bentov et al. 2012); fossils indicate that phosphatic skeletons were more widespread during the Cambrian Period, characterizing early chaetognath teeth and skeletons in a limited number of now extinct lineages (Zhuravlev and Wood 2008; Maloof et al. 2010). Silica biomineralization is even more restricted among animals, characterizing only early branching sponges (Müller et al. 2007), with minor occurrences in calcareous brachiopods and a few arthropods (references in Knoll 2003). Among seaweeds, calcite and aragonite also dominate skeletal biomineralization, occurring among the green, red, and brown algae (Raven and Giordano 2009). Land plants are different, precipitating amorphous silica within epidermal cells (Raven 1983).

The greater phylogenetic distribution of mineralized skeletons reflects a second shortcoming of al-Razi’s classification. Many eukaryotes are neither animal nor vegetable, instead belonging to diverse clades grouped informally (and paraphyletically) as protists, and these microscopic eukaryotes paint a different picture of skeletal biomineralization. Testate and scaleforming organisms are widely, if discontinuously distributed among protists. They may serve a number of functions, but ballast and defense against predation probably explain many such structures (e.g., Cohen and Knoll 2012). Calcite mineralizes the tests of some foraminiferans (Lipps 1973) and the scales of coccolithophorid algae (Young and Henriksen 2003), and rare occurrences of carbonate biomineralization have been reported among dinoflagellates and in at least one amoebozoan. Phosphatic biomineralization is exceedingly rare in protists, being reported only in the scales of a single freshwater green phytoflagellate (Domozych et al 1991, but see Raven and Knoll 2010) and in the test lining of a freshwater amoebozoan (Hedley et al. 1977). In contrast, amorphous silica occurs in diverse protistan clades (Preisig 1994, Fig. 1), including the choanoflagellates, rhizarians (four or more independent origins), haptophytes, 
heliozoans, amoebozoans (at least three independent origins), and stramenopiles (at least three origins). New occurrences continue to be discovered, for example, the report of a ciliate that coats its resting spores with granules of amorphous silica (Foissner et al. 2009). Why should silica precipitation be so prominent among microscopic eukaryotes, when Ca-minerals dominate in the macroscopic biota?

\subsection{Silica Use by Protists}

Silica might seem an unusual choice for skeletal mineralization, given its low concentrations in seawater and most terrestrial environments. The physiological cost of biomineralization, however, scales with saturation state, not with absolute abundance. Seawater becomes saturated with respect to amorphous silica at concentrations of about $60 \mathrm{ppm}$, and in pre-diatom oceans, it is likely that marine waters were commonly at or near this saturation state (Siever 1992), or even higher (Grenne and Slack 2003). Silica concentrations can also be high in rivers, lakes and groundwaters -- waters that are commonly undersaturated with respect to calcium carbonate minerals.

Of course, the upper ocean is also oversaturated with respect to calcium carbonate minerals, and so saturation sate alone cannot account for the widespread use of silica in protestant skeletons. Perhaps the key lies in material properties. Amorphous silica can be fashioned into complex structures on a scale of microns or less, enabling silica-precipitating microorganisms to make strong, lightweight structures with pores and struts that are little approximated by carbonate-precipitating protists. Moreover, both observation and experiment show that amorphous silica precipitates readily on long chain polyamines and structural proteins such as chitin and collagen which, themselves, can be fashioned into structures of outstanding complexity on micron- or even submicron spatial scales (Ehrlich 2011). That is, many protists, whether mineralized or not, fashion organic scales of exquisite complexity. The advantage, then, of amorphous silica in protistan biomeralization may be that it can reinforce those fine-sccale constructions free of the crystallographic constraints that influence carbonate biomineralization (e.g., Young and Henriksen 2003). Together, the constructional properties of these organic molecules and the silica that binds to them may account for the repeated evolution of silica biomineralization in scale- and test-forming protists. 
Our understanding of silica biomineralization in protists stems almost entirely from laboratory studies of diatoms (reviewed by Kröger and Poulsen 2008, Wallace et al 2012). The concentration of orthosilicic acid in the internal vesicles where frustule formation occurs is commonly high relative to the ambient environment, indicating that diatoms can pump silica across membranes (Hildebrand 2000). Nucleation appears to occur on a polysaccharide-rich organic template, catalyzed by long chain polyamines and silaffin proteins (Kröger and Poulsen 2008). Silicification in sponges involves a different set of organic constituents (references in Wallace et al 2012), demonstrating that distinct proteins and polysaccharides have been recruited for silica skeletogenesis in different silicifying clades. In this regard, it is curious that preliminary molecular research on silica precipitation in choanoflagellate loricae (e.g., Gong et al. 2010) indicates that silicon transporters in this group are related to those in diatoms, implying lateral genetic transfer (Marron et al 2013). Not much is known about the molecular biology of silification in radiolaria or other groups.

Various functions have been inferred for silicified tests and scales in protists. Defense against grazers is commonly invoked, and Hamm et al. (2003, Hamm 2005) have demonstrated experimentally that diatom frustules have a mechanical strength that would deter mandibulate microzooplankton predators such as copepods, euphausiids, and, in fresh water, cladocerans. Indeed, a portion of the diatoms ingested by both copepods and euphausiids has been observed to survive passage through the gut unscathed (Fowler and Fisher 1983). Other functions have been proposed for diatom frustules, involving buoyancy, light modulation, catalysis of carbon assimilation, maintenance of shape and orientation, and defense against viruses (references in Finkel and Kotrc 2010) - these are not mutually exclusive hypotheses. Whether the siliceous scales of chrysophytes, heliozoans and prymensiophytes would protect against microarthropod grazing is open to question, but they might well deter protistan predators such as ciliates. A correlation between the test morphology and feeding mode of radiolarians suggests that siliceous tests in these protists may also play a role in providing shape and structure to the cytoplasm (Matsuoka 2007), supporting prey-capturing pseudopodia analogous to the vertebrate skeletomuscular system (Anderson 1983), and perhaps in orienting cells within the water column (Haeckel 1887). Sorting out functional hypotheses might be aided by surveying the geologic history of silica-precipitating protists. 


\subsection{A Short History of Protistan Biomineralization}

The oldest eukaryotic microfossils that might be interpreted in terms of defense against predators are vase-shaped tests and scales, both found in 800-740 million year old (Ma) rocks. Ten to thirty $\mu \mathrm{m}$ scales preserved in platform carbonates from northwestern Canada were originally interpreted as siliceous, based largely on comparisons to scales formed today by chrysophyte algae (Allison and Hilgert 1986). In a restudy, Cohen et al. (2011) used Raman and fluorescence spectroscopy to show that the scales actually consist of apatite in an organic matrix. Systematic investigation of scales freed by acid digestion from host rocks documents some three dozen morphospecies, the highest diversity of eukaryotic fossils found to date in any pre-Ediacaran rocks (Cohen and Knoll 2012). Many protists form scales, but none of the ca. 800 Ma scales can be allied unambiguously to an extant clade. Indeed, it remains an open question whether the apatite within the fossils reflects biomineralization or early diagenetic phosphatization, as observed in small shelly fossils from Cambrian strata. If the observed phosphate was emplaced diagenetically, it is probable that the scales were originally organic, as we know of no fossils in which phosphate has replaced pre-existing silica.

The other microfossils of interest are assemblages of ca. $100 \mu \mathrm{m}$ long, vase-shaped tests found in 740-780 Ma rocks from around the world but preserved especially well in the Grand Canyon. At least some of these tests can be assigned to clades of testate amoebae in the Amoebozoa (Porter et al. 2003). A subpopulation displays abundant ovoid holes 5-10 $\mu \mathrm{m}$ in maximum dimension and arranged in a hexagonally closed-packed pattern. Porter et al. (2003) hypothesized that these holes reflect the positions of scales that covered the test in life, much like the extant testate rhizarian Euglypha. More recent molecular clock estimates suggest that euglyphids originated long after $750 \mathrm{Ma}$, requiring that any comparison with the Grand Canyon fossils reflect analogy rather than homology (Berney and Pawlowski 2006). Also, whether the inferred scales were siliceous or not remains unknown. Thus, while-pre-Edicaran rocks preserve evidence for protistan defensive structures and include possible candidates for early skeletal biomineralization, it is only in the Ediacaran Period that we begin to see unambiguous evidence of mineralized skeletons. 
Microbial reefs from late Ediacaran (550-542 Ma) platform carbonates contain locally abundant populations of at least three biomineralizing animals. As in the case of older protists, both the systematic relationships and original mineralogy of these fossils remain questions for debate. Much opinion, however, places tubular Cloudina and goblet-shaped Namacalathus among the Cnidaria, and the Namapoeikea with calcareous sponges (Grotzinger et al. 2000, Wood et al. 2005). All had thin calcified surfaces, possibly aragonitic in Namapoeikea, but less readily interpreted in the other taxa (Porter 2010).

A new age of biomineralization began with the Cambrian Period. Molecular clock estimates suggest that silica-precipitating sponges evolved as much as 750-800 Ma (Sperling et al. 2010), but unambiguous spicules occur only in uppermost Ediacaran rocks (Brasier et al 1997), and sponges first rose to biogeochemical prominence in the marine silica cycle only with a Cambrian radiation of hexactinellids and siliceous demosponges (Maliva et al. 1989, Carrera and Botting 2008). Calcareous sponges also radiated in Cambrian oceans, most prominently the ecologically important but stratigraphically short-lived archaeocyathids (Debrenne 2007). Cnidarians show evidence of Cambrian diversification, but massively calcifying corals spread only during the succeeding Ordovician Period (Park et al 2011). And among bilaterian animals, calcareous and, to a lesser extent, phosphatic skeletons evolved independently in diverse phyla, filling most of the skeletal morphospace that would be occupied during the Phanerozoic Eon (Thomas et al 2000). There is broad agreement that the polyphyletic (Knoll 2003) evolution of mineralized skeletons reflects an increase in metazoan predation, at least in part (Bengtson and Conway Morris 1992). Despite the evolution of mineralized skeletons in many clades, however, skeletons played a relatively minor role in the carbonate cycle of Cambrian oceans (Pruss et al. 2010, 2011; Creveling et al 2013). The evolution of biominerlaized structures reflects cost:benefit ratios, and in this context, the limited biogeochemical importance of carbonate skeletons in Cambrian oceans may relate to limited predation pressure (and hence, low benefit, given the cost of skeleton precipitation), warm oceans with anoxia in subsurface water masses (a circumstance that, like ocean acidification, increases the cost of carbonate precipitation by lowering saturation level; Knoll and Fischer 2011), or both. Only with renewed Ordovician diversification did highly calcified, sessile benthic invertebrates become established as dominant constituents of marine carbonates (Pruss et al. 2010). 
What about Cambrian protists? Did they participate in the "Great Leap Forward” of biomineralization? Protists certainly radiated in Cambrian oceans along with animals; this is seen clearly in the records of cysts made predominantly by algae (Knoll 1994, Vidal and Moczydlowska 1997) and in the diversification of benthic foraminiferans with agglutinated skeletons (McIlroy et al 2001). The main actors in protist biomineralization, however, appear to have been the silica-precipitating Radiolaria. Radiolarian fossils have been described from lower Cambrian strata (Pouille et al. 2011) and show gradual diversification throughout the period. Like animals, however, radiolarians really emerged as important components of the marine silica cycle with renewed expansion during the Ordovician Period (Maliva et al. 1989, Won and Iams 2011).

Among animals, novel instances of skeletal biomineralization tailed off after the Ordovician Period, but this does not seem to be true of protists. The vagaries of preservation may bias the protistan record toward younger occurrences, as may the ecological restriction of some biomineralizing clades to fresh water and wet soil, environments less likely to be preserved in older successions. Nonetheless, innovations in protistan biomineralization appear to have continued and, likely, accelerated over the past 500 million years (Figure 2). Foraminifera, for example, can have organic, agglutinated, or calcareous tests (Lipps 1973). While molecular clocks suggest a Neoproterozoic origin for the clade (Groussin et al. 2011), the oldest widely accepted foram fossils are agglutinated tests in Cambrian rocks (McIlroy et al 2001). Calcareous tests emerged with the mid-Paleozoic radiation of miliolids and, again, with the independent acquisition of calcitic tests by rotaliids during the Triassic Period (Groussin et al. 2011). Haptophyte algae also evolved calcitic scales (coccoliths) toward the end of the Triassic Period, about 210 Ma (Young and Henriksen 2007).

Experiments have shed light on calcification in both forams and coccolithophorid haptophytes, and in both cases, ions derived from seawater are pumped into a membrane-defined space where carbonate (in at least some cases, initially as amorphous calcium carbonate) forms on a macromolecular template, perhaps facilitated by physiological modulation of $\mathrm{pH}$ (e.g., Paasche 2002, Marsh 2003, Erez 2003, Bentov et al. 2009). Together, the radiation of coccolithophorids and the polyphyletic (Ujiié et al. 2008) expansion of calcified forams into the marine plankton changed the nature of carbonate deposition in the oceans (Zeebe and Westbroek 2003). 
Despite the early evolution of scales in eukaryotes (Cohen and Knoll 2012), silica biomineralization of protistan scales also appears to be, in large part, a much younger phenomenon. Molecular clocks suggest that prymensiophytes with siliceous scales appeared no earlier than about 300 Ma (Berney and Pawlowski 2006). Euglyphid rhizarians, known to produce siliceous scales that tile their tests, are thought on the basis of molecular clock estimates to have Mesozoic origins (Berney and Pawlowski 2006, Brown and Sorhannus 2010), and the siliceous microfossils of ebridians, placed within the Rhizaria on the basis of molecular sequence comparions (Hoppenrath and Leander 2006), date back only to the Paleocene (Ernissee and McCartney 1993). Similarly, the array of silica-precipitating clades within the stramenopiles -chrysophytes, synurophytes, dictyochophytes (silicoflagellates), and diatoms (Andersen 2004) appear on the basis of both fossils and molecular clocks to characterize only Mesozoic and younger ecosystems (chapters in Falkowski and Knoll 2007; Brown and Sorhannus 2010).

Diatoms, of course, are the crown jewels among silica-precipitating protists, fashioning frustules of $\mathrm{SiO}_{2}$ that inspire technological innovations in lightweight design (Gordon et al 2009). Diatoms first appear as fossils in uppermost Jurassic rocks and diversify through the Cretaceous Period and into the Cenozoic Era, both in the oceans and in non-marine environments (Kooistra et al. 2007). These algae may be responsible for as much as twenty percent of Earth’s total primary production, and they dominate the marine silica cycle, quantitatively removing dissolved silica from surface water masses (Maliva et al 1989, Maldonado et al. 2011). Moreover, the ballast provided by mineralized frustules contributes to the dominant influence of diatoms in marine export production (Smetacek 1999).

This brief outline of the evolutionary history of biomineralizing protists prompts two questions: why silica and why so late in the evolutionary day? As noted above, the first question finds answer in the material properties of amorphous silica and the biomolecules onto which it is precipitated. Amorphous silica can be formed into strong porous and strutted structures on lengths scales of less than a micron, making it ideal for protistan biomineralization. In some ways, the question of mineral utilization should really be: why don't animals and macroscopic algae make greater structural use of silica, and here the answer probably lies in its low solubility in fresh and marine waters - there simply isn't enough silica in seawater to make large skeletons from a physiologically realistic volume of water (Wallace et al. 2012). Silica found in freshwater water algae, soil protists and vascular plants -- also fits the environmental 
constraints of terrestrial environments; most rivers, lakes and groundwaters are undersaturated with respect to calcite and aragonite.

Why so many armored protists (both siliceous and calcareous) gained importance only during the past 200 million years is a more intriguing question. As noted earlier, scales have been produced by protists since the Neoproterozoic Era (Cohen and Knoll 2012), and while it is impossible to know whether or not groups such as testate amoebozoans, testate rhizarians, and heliozoans precipitated silica in these oceans, there is little evidence for such biosynthesis, and any protistan biomineralization must have played an insignificant role in the marine silica cycle (Maliva et al. 1989). The late geological appearance of siliceous scales certainly has a phylogenetic component to it: silica-precipitating haptophytes and stramenopiles did not exist before the latest Paleozoic or early Mesozoic Era. This, however, does not by itself resolve the issue, as silica precipitation requires a functional as well as phylogenetic explanation. The Mesozoic to earliest Cenozoic appearance of siliceous skeletons in diatoms, silicoflagellates, chrysophytes, and ebridians, along with the evolution of calcitic tests in coccolithophroids and the expansion of calcified forams into the water column, is consistent with an increase in predation by microzooplankton. A general increase in predation pressure in the oceans occurred on this time scale (Vermeij 1977), as did a shift in shelf primary producers from green flagellates and cyanobacteria to dinoflagellates, coccolithophorids and diatoms (Falkowski et al. 2004). Perhaps radiating primary producers precipitated evolutionary changes in microzooplankton and throughout marine food webs (e.g., Knoll 2013), with predation pressure feeding back onto both photosynthetic and heterotrophic protists. A nearly monotonic increase in ${ }^{87} \mathrm{Sr} /{ }^{86} \mathrm{Sr}$ of seawater over the past 150 million years also suggests that continental weathering provided increasing amounts of dissolved silica to the oceans. Over time, then, silica flux may have increased even as surface reservoir size declined.

\subsection{The evolutionary consequences of diatom radiation for silica biomineralizers}

Despite the widespread removal of carbonates from the oceans by marine animals and protists, surface oceans remain oversaturated with respect to calcite and aragonite, and there is little 
evidence that carbonate precipitation by any one clade has influenced the evolutionary trajectories of other calcareous species. This is, however, not the case for biological participants in the marine silica cycle. Skeleton-forming organisms deplete silica levels in surface oceans to values an order of magnitude lower than those that characterized seawater before the advent of siliceous skeletons (Siever, 1992), and one might reasonably expect that the secular decline in silica availability has impacted the evolutionary trajectories of silica-precipitating animals and protists.

Consistent with paleontological evidence that they first evolved in silica-rich Neoproterozoic and Cambrian oceans, sponges (at least the few species that have been examined experimentally) show maximum uptake efficiency at dissolved silica levels much higher than those found in modern surface oceans (Maldonado et al. 2011). Siliceous sponges can be locally important in coastal ecosystems (Maldonado et al. 2010), but the fossil record indicates that they have progressively declined in ecological importance among shelf communites through the late Mesozoic and Cenozoic eras (Maliva et al., 1989). Indeed, when grown at silica concentrations similar to those inferred for a pre-diatom world, some modern sponges produce spicule morphologies not seen in the geologic record since the Jurassic Period (Maldonado et al. 1999). It has been hypothesized that the inefficient uptake of silica by sponges relative to diatoms accounts for their ecological retreat to deeper waters (Maldonado et al. 2012) - diatom success, then, has impacted sponge evolution by restricting many silica-precipitating species to deeper seafloors where silica concentrations are relatively high and diatoms that compete for silica are absent.

Much like sponges, the Radiolaria also evolved in silica-rich oceans. Their fossil record has revealed a remarkable trajectory of morphological change, especially over the course of the Cenozoic Era. During the same time interval that the diatoms rose to their present-day diversity and dominance over the marine silica cycle, the shell weight of radiolarians in low latitude oceans declined severalfold (Harper and Knoll 1975). Morphological measurement has since shown that this decline is due to a decrease in silicification, rather than a reduction in size, with shell walls becoming thinner and more porous through time (Lazarus et al. 2009). Although most modern surface ocean waters have extremely low silica concentrations, this is not true of the high-latitude Southern Ocean, where upwelling has supplied silica-rich water to the surface since the late Eocene Epoch. Interestingly, radiolarian assemblages from those southern high latitude 
regions do not show a reduction in silicification over the Cenozoic (Lazarus et al. 2009), further supporting the conclusion that the evolutionary trends in radiolarian biomineralization happened in response to changing silica availability. Radiolarians also appear to be less common in shelf environments than they were in earlier oceans (Racki and Cordey 2000), arguably another habitat shift in response to the radiation of diatoms across continental shelves.

Though the known fossil record of the silicoflagellates extends only to the Mesozoic Era (Bukry 1981), the decline of silica availability in surface waters of Cenozoic oceans should still have affected their evolution. Although there appears to have been no change in the average silicification of silicoflagellates over the past 60 million years (van Tol and Finkel 2012) of the sort seen in Radiolaria, shifting costs and benefits of biomineralization may nonetheless have impacted silicoflagellate evolution. Silicoflagellates with spines show quite a different trajectory of morphological change from those without spines, which are also larger. While the larger, spineless forms decreased in size and eventually became extinct, the smaller, spined forms increased the number of spines while their size remained constant. Van Tol and Finkel (2012) suggested that these two groups may have employed two different strategies to avoid predation-large cell size versus anti-grazing spines. Because of their larger surface to area ratio and consequently higher nutrient uptake rate, the benefit of spines in the smaller, spined forms could have outweighed the rising metabolic costs of uptake with declining silica availability, even as those costs began to exceed the benefit of large size for the spineless forms.

Diatoms may have been the major agents of geochemical change in the Phanerozoic silica cycle, but one might nonetheless expect these changes to have affected their own evolution. Indeed, anecdotal evidence suggests that robust and heavily silicified diatoms are common in Cretaceous and early Cenozoic assemblages, but are gradually replaced by more delicate forms (Armstrong and Brasier, 2005, Barron and Baldauf 1995). For example, the Cretaceous species of the genus Hemiaulus are heavily silicified, while those occurring in Cenozoic deposits are more lightly silicified (Round et al. 1990). This pattern was borne out in a semi-quantitative survey of three well-preserved diatom assemblages spanning from the Early Cretaceous to the Neogene, which showed a decline in percent silicification of frustule walls (Finkel and Kotrc 2010). While thinner walls are more common in the younger assemblages, the pattern is complicated by the observation that silicification is actually inversely proportional to wall thickness. Thus, while there are more thinner-walled forms with time, these lack the larger 
pores and chambered, multiple-layer structure of many thicker-walled forms, meaning the decline in percent silicification is less predicted by wall thickness alone.

Studies of extant diatoms grown in culture under varying silica concentrations have also shed light on how declining silica availability has affected diatom evolution. When measured across a range of concentrations, the kinetics of silica uptake in diatoms seem to be multiphasic, which may suggest that multiple silica uptake systems evolved over the course of declining silica concentrations (Finkel et al. 2010). While the degree of silicification and the frustule micromorphology of several species changed with silica concentration in culture experiments, the oldest species examined was also the most heavily silicified — consistent with having evolved in a higher-silica oceans than the younger, less-silicified species.

This is not to suggest that silica alone has driven morphological trends in the evolution of diatoms or any other clade; surely silicifying organisms have responded through time to secular variations in nutrient abduance, temperature, ocean circulation and grazing pressure.

Nonetheless, research on the fossil records of several silica-precipitating clades indicates that the remarkable evolutionary success of diatoms in the world's oceans, with its attendant consequences for silica availability in surface water masses, has impacted the evolution of all major participants in the marine silica cycle - including diatoms, themselves.

\subsection{Summary}

Both living and fossil protists show evidence of skeletal biomineralization, documenting a structurally and mineralogically diverse range of lightweight bioconstructions. Protistan fossils and phylogeny do not follow predictions made on the basis of animal biology: Biomineralization predominantly uses amorphous silica, and new silica-precipitating clades have continued to arise through time. The material properties of amorphous silica and the biomolecules on which it precipitates open up new opportunites for complex microstructures that play a number of roles in protistan biology, including - but not restricted to - defense against microarthropod grazers. At the same time, the remarkable rise of diatoms to ecological prominence in the oceans has depleted silica concentrations in the mixed layer of most oceans, imposing a significant constraint on the evolution of protists that participate in the marine silica cycle. The bioconstructions observed in living marine protists reflect both the opportunities and constraints 
associated with silica biomineralization, and the increasingly more economical use of silica through time documented for some clades, has the potential to guide future thinking about improving biomimetic designs while conserving materials. In this respect, the long evolutionary history of biomineralizing protists may inspire novel approaches to technology.

\section{Figure Captions}

Figure 1. A phylogeny of biomineralizing eukaryotes, drawn from papers cited in the text. Letters in ovals indicate major occurrence of biomineralized skeletons of calcium carbonate (C), Ca-phosphate (P), amorphous silica (S), or, uniquely in the case of acantharians (strontium sulfate). Grey letters indicate minor occurrences within a clade..

Figure 2. Geologic history of biomineralizing protistan clades, drawn from the fossil record (solid lines) or molecular clock estimates (dashed lines). Data sources cited in text. 


\section{Bibliography}

Allison CW, Hilgert JW (1986) Scale microfossils from the Early Cambrian of northwest Canada. J Paleontol 60:973-1015

Andersen RA (2004) Biology and systematics of heterokont and haptophyte algae. Amer J Bot 91:1508-1522

Anderson OR (1983) Radiolaria. Springer Verlag, New York

Armstrong H and Brasier M (2005) Microfossils. Blackwell Publishing, Malden, MA

Barron J and Baldauf J (1995) Cenozoic marine diatom biostratigraphy and applications to paleoclimatology and paleoceanography. In Blome CD, Whalen PM, Reed KM (eds) Siliceous Microfossils. Paleontol. Soc. Short Courses Paleontol. Number 8, p 107-118

Bengtson S, Conway Morris S (1992) Early radiation of biomineralizing phyla. In Lipps JH, Signor PW (eds) Origin and Early Evolution of the Metazoa. Plenum, New York, p 447-481

Bentov S, Brownlee C, Erez J (2009) The role of seawater endocytosis in the biomineralization process in calcareous foraminifera. Proc Nat Acad Sci USA 51:21500-21504

Bentov S, Zaslansky P, Al-Sawalmih A et al (2012) Enamel-like apatite crown covering amorphous mineral in a crayfish mandible. Nature Comm doi: 10.1038/ncomms1839

Berney C, Pawlowski J (2006) A molecular time-scale for eukaryote evolution recalibrated with the continuous microfossil record. Proc R Soc Lond Ser B 273:1867-72

Brasier M, Green O, Shields, G (1997) Ediacarian sponge spicule clusters from southwestern Mongolia and the origins of the Cambrian fauna. Geology 25:303-306

Brown JW, Sorhannus U (2010) A molecular genetic timescale for the diversification of autotrophic stramenopiles (Ochrophyta): Substantive underestimation of putative fossil ages. PLoS ONE 5(9) doi:10.1371/journal.pone.0012759

Bukry D (1981) Synthesis of silicoflagellate stratigraphy for Maestrichtian to Quaternary marine sediment. Soc of Econ Paleont and Min Spec Pub 32:433-444

Burki F, Shalchian-Tabrizi K, Pawlowski J (2008) Phylogenomics reveals a new 'megagroup' including most photosynthetic eukaryotes. Biology Lett 4:366-369

Carrera MG, Botting JR (2008) Evolutionary history of Cambrian spiculate sponges:

Implications for the Cambrian evolutionary fauna. Palaios 23:124-138 
Creveling JC, Knoll AH, Fernández Remolar D et al. (2013) Geobiology of a Lower Cambrian carbonate platform, Pedroche

Formation, Spain. Palaeogeography Palaeoclimatology Palaeoecology, published online ahead of print, doi: 10.1016/j.palaeo.2013.06.015

Cohen PA, Knoll AH (2012) Neoproterozoic scale microfossils from the Fifteen Mile Group, Yukon Territory. J Paleontol 86:775-800

Cohen PA, Schopf JW, Butterfield NJ et al (2011) Phosphate biomineralization in midNeoproterozoic protists. Geology 39:539-542

Cuif J-P, Dauphin Y, Sorauf JE (2011) Biominerals and fossils through time. Cambridge University Press, Cambridge UK

Debrenne F (2007) Lower Cambrian archaeocyathan bioconstructions. Comptes Rendus Palevol 6:5-19

Domozych D, Wells B, Shaw P (1991) Basket scales of the green-alga, Mesostigma viride chemistry and ultrastructure. J Cell Sci 100:397-407

Ehrlich H (2010) Chitin and collagen as universal and alternative templates in biomineralization. Int Geol Rev 52:661-699

Erez J (2003) The source of ions for biomineralization in foraminifera and their implications for paleoceanographic proxies. Rev Mineral Geochem 54:115-149

Ernissee JJ, McCartney K (1992) Ebridians. In Lipps JH (ed) Fossil prokaryotes and protists. Blackwell Scientific, Oxford, p 131-140

Falkowski P, Knoll H (eds) (2007) The evolution of primary producers in the sea. Elsevier, Burlington

Falkowski PG, Katz ME, Knoll AH et al (2004) The evolution of modern eukaryotic phytoplankton. Science 305: 354-360

Finkel ZV, Kotrc B (2010) Silica use through time: macroevolutionary change in the morphology of the diatom fustule. Geomicrobiol J 27:596-608

Finkel ZV, Matheson KA, Regan KS et al. (2010) Genotypic and phenotypic variation in diatom silicification under paleo-oceanographic conditions. Geobiology 8, 433-445

Foissner W, Weissenbacher B, Krautgartner W-D et al (2009) A cover of glass: first report of biomineralized silicon in a ciliate, Maryna umbrellata (Ciliophora: Colpodea). J Euk Microbiol 56:519-530. 
Fowler S, Fisher N (1983) Viability of marine phytoplankton in zoo- plankton fecal pellets. Deep-Sea Res 30:963-969

Frankel RB, Bazylinski DA, Schüler D (1998) Biomineralization of magnetic iron minerals in magnetotactic bacteria. J. Supramol Sci 5:383-390

Gong N, Wiens M, Schröder et al. (2010) Biosilicification of loricate choanoflagellate: organic composition of the nanotubular siliceous costal strips of Stephanoeca diplocostata. J Exp Biol 213:3575-3585

Gordon R, Losic D, Tiffany MA et al (2009) The glass menagerie: diatoms for novel applications in nanotechnology. Trends Biotechnol 27:116-127

Grenne, T; Slack, JF (2003) Paleozoic and Mesozoic silica-rich seawater: Evidence from hematitic chert (jasper) deposits. Geology 31:319-322

Grotzinger JP, Watters, Knoll AH (2000) Calcareous metazoans in thrombolitic bioherms of the terminal Proterozoic Nama Group, Namibia. Paleobiology 26:334-359

Groussin M, Pawlowski J, Yang Z (2011) Bayesian relaxed clock estimation of divergence times in foraminifera. Mol Phyl Evol 61:157-166

Haeckel E (1887) Report on the Radiolaria collected by H.M.S. Challenger during the years 1873-1876. Rep. Sci. Results, Challenger, Zool. 18:clxxxviii + 1803 p

Hamm CE (2005) The evolution of advanced mechanical defenses and potential technological applications of diatom shells. J Nanosci Nanotechnol 5:108-199

Hamm CE, Merkel R, Springer O et al (2003) Architecture and material properties of diatom shells provide effective mechanical protection. Nature 421:841-843.

Harper HE Jr, Knoll AH (1975) Silica, diatoms, and Cenozoic radiolarian evolution. Geology 3:175-177

Hedley R, Ogden C, Mordan N (1977) Biology and fine structure of Cryptodifflugia oviformis (Rhizopdea: Protozoa). Bull. Br. Mus. Nat. Hist. (Zool.) 30:313-328

Hildebrand M (2000) Silicic acid transport and its control during cell wall silicification in diatoms. In Bäuerlein E (ed) Biomineralization. Springer-Verlag, Weinheim, p 171- 188

Hoppenrath M, Leander BS (2006) Ebriid phylogeny and the expansion of the Cercozoa. Protist $157: 279-290$

Knoll AH (1994) Proterozoic and Early Cambrian protists: evidence for accelerating evolutionary tempo. Proc Nat Acad Sci USA 91:6743-6750 
Knoll AH (2003) Biomineralization and evolutionary history. Rev Mineral Geochem 54:329356

Knoll AH (2013) Systems paleobiology. Geological Society of America Bulletin 125:3-13

Knoll AH, Fischer WW (2011) Skeletons and ocean chemistry: the long view. In: Gattuso JP, Hansson L (eds) Ocean acidification. Oxford University Press, Oxofrd UK, pp. 67-82

Konhauser KO, Riding R (2012) Bacterial biomineralization. In: Knoll AH, Canfield DE, Konhauser KO (eds) Fundamentals of geobiology. Wiley-Blackwell, Chichester, pp 105-130

Kooistra WHCF, Gersonde R, Medlin LK et al (2007) The origin and evolution of the diatoms: their adaptation to a planktonic existence. In Falkowski P, Knoll AH (eds) The evolution of primary producers in the sea. Elsevier, Burlington, pp. 207-249

Kröger N, Poulsen, N (2008) Diatoms-from cell wall biogenesis to nanotechnology. Ann Rev Genetics 42:83-107

Kröger N, Sumper M (2004) Silica formation in diatoms: the function of long-chain polyamines and silaffins. J. Mater. Chem. 14:2059-2065

Lazarus DB, Kotrc B, Wulf G et al (2009) Radiolarians decreased silicification as an evolutionary response to reduced Cenozoic ocean silica availability. Proc Nat Acad Sci USA 106:9333-9338

Lipps JH (1973) Test structure in Foraminifera. Ann Rev Microbiol 27:471-488

Maldonado M, Carmona MC, Uriz MJ et al (1999) Decline in Mesozoic reef-building sponges explained by silicon limitation. Nature 401:785-788

Maldonado M, Riesgo A, Bucci A et al (2010) Revisiting silicon budgets at a tropical continental shelf: Silica standing stocks in sponges surpass those in diatoms. Limnol Oceanogr 55: 20012010.

Maldonado M, Navarro L, Grasa A et al (2011) Silicon uptake by sponges: a twist to understanding nutrient cycling on continental margins. Nature Sci Rep 1:1-8

Maldonado M, Cao H, Cao X et al (2012) Experimental silicon demand by the sponge Hymeniacidon perlevis reveals chronic limitation in field populations. Hydrobiologia 687:251257.

Maliva R, Knoll AH, Siever R (1989) Secular change in chert distribution: a reflection of evolving biological participation in the silica cycle. Palaios 4:519-532

Maloof AC, Porter SM, Moore JL et al (2010) The earliest Cambrian record of animals and ocean geochemical change. Geol Soc Am Bull 122:1731-1774. 
Marron AO, Alston MJ, Heavens D, Akam M, Caccamo M, Holland PWH, Walker G (2013) A family of diatom-like silicon transporters in the siliceous loricate choanoflagellates. Proc R Soc B - Biol Sci 280, Article Number 20122543.

Marsh ME (2003) Regulation of $\mathrm{CaCO}_{3}$ formation in coccolithophores. Comp Biochem Physiol B: Biochem Mol Biol 136:743-754

Matsuoka A (2009) Living radiolarian feeding mechanisms: new light on past marine ecosystems. Swiss J Geosci 100:273-279

Mcllroy D, Green OR, Brasier MD (2001) Palaeobiology and evolution of the earliest agglutinated Foraminifera: Platysolenites, Spirosolenites and related forms. Lethaia 34:13-29

Müller WEG, Li J, Schröder HC et al (2007) The unique skeleton of siliceous sponges (Porifera; Hexactinellida and Demospongiae) that evolved first from the Urmetazoa during the Proterozoic: a review. Biogeosciences 4:219-232

Parfrey LW, Grant J, Tekle YI et al (2010) Broadly sampled multigene analyses yield a wellresolved eukaryotic tree of life. Syst Biol 59:518-533

Park T-Y, Woo J, Lee D-J et al (2011) A stem-group cnidarian described from the mid-Cambrian of China and its significance for cnidarian evolution. Nature Comm doi: 10.1038/ncomms1457

Paasche E (2002) A review of the coccolithophorid Emiliania huxleyi (Prymnesiophyceae), with particular reference to growth, coccolith formation and calcification - photosynthesis interactions. Phycologia 40:503-529

Porter SM (2010) Calcite and aragonite seas and the de novo acquisition of carbonate skeletons. Geobiology 8:256-277

Porter SM, Meisterfeld R, Knoll, AH (2003) Vase-shaped microfossils from the Neoproterozoic Chuar Group, Grand Canyon: A classification guided by modern testate amoebae. J Paleontol 77:409-429

Pouille L, Obut O, Danelian T et al (2011) Lower Cambrian (Botomian) polycystine Radiolaria from the Altai Mountains (southern Siberia, Russia) Comptes Rendus Palevol 10:627-633

Preisig HR (1994) Siliceous structures and silicification in flagellated protists. Protoplasma 181:29-42

Pruss SA, Finnegan S, Fischer WW et al (2010) Carbonates in skeleton-poor seas: New insights from Cambrian and Ordovician strata of Laurentia. Palaios 25:73-84

Pruss SA, Clemente H, LaFlamme M (2012) Early (Series 2) Cambrian archaeocyathan reefs of southern Labrador as a locus for skeletal carbonate production. Lethaia 45:401-410 
Racki G, Cordey F (2000) Radiolarian palaeoecology and radiolarites: is the present the key to the past? Earth-Sci Rev 52:83-120

Raven JA (1983) The transport and function of silicon in plants. Biol Rev 58:179-207

Raven JA, Waite AM (2004) The evolution of silicification in diatoms: inescapable sinking and sinking as escape? New Phytol 162:45-61

Raven JA, Giordano M (2009) Biomineralization by photosynthetic organisms: Evidence of coevolution of the organisms and their environment? Geobiology 7: 140-154

Raven JA, and Knoll AH (2010) Non-skeletal biomineralization in protists: matters of moment and gravity. Geomicrobiol J 27:1-13

Round FE, Crawford RM, Mann DG (1990) The diatoms: biology \& morphology of the genera. Cambridge Univ Press, Cambridge UK

Siever R (1992) The silica cycle in the Precambrian. Geochim Cosmochim Acta 56: 3265-3272

Sperling EA, Robinson JM, Pisani D et al (2010) Where's the glass? Biomarkers, molecular clocks, and microRNAs suggest a 200-Myr missing Precambrian fossil record of siliceous sponge spicules. Geobiology 8:24-36

Strathern P (2005) A brief history of medicine: from Hippocrates' four humours to Crick and Watson's double helix. Robinson, London

Thomas RDK, Shearman RM, Stewart CW (2000) Evolutionary exploitation of design options by the first animals with hard skeletons. Science 288:239-1242.

van Tol HM, Irwin AJ, Finkel ZV (2012) Macroevolutionary trends in silicoflagellate skeletal morphology: the costs and benefits of silicification. Paleobiology 38:391-402

Ujiié Y, Kimoto K, Pawlowski J (2008) Molecular evidence for an independent origin of modern triserial planktonic foraminifera from benthic ancestors. Mar Microapelontol 69:334-340

Vermeij GJ (1977) The Mesozoic marine revolution: evidence from snails, predators and grazers. Paleobiology 3:245-258

Vidal G, MoczydlowskaVidal M (1997) Biodiversity, speciation, and extinction trends of Proterozoic and Cambrian phytoplankton. Paleobiology 23:230-246

Wallace AF, Wang D, Hamm LM et al (2012) Skeletal formation in eukaryotes. In: Knoll AH, Canfield DE, and Konhauser K (eds) Fundamentals of geobiology. Wiley-Blackwell, Chichester, p 150-187 
Weiner S, Dove PM (2003) An overview of biomineralization processes and the problem of the vital effect. Rev Mineral Geochem 54:1-29

Won M-Z, Iams WJ (2011) Earliest Arenig radiolarians from the Cow Head Group, western Newfoundland. J Paleontol 85:156-177

Wood RA, Grotzinger JP, Dickson JAD (2002) Proterozoic modular biomineralized metazoan from the Nama Group, Namibia. Science 296:2383-2386

Yoshida M, Noel M, Nakayama T et al (2006) A haptophyte bearing siliceous scales: ultrastructure and phylogenetic position of Hyalolithus neolepis gen. et sp. nov.

(Prymnesiophyceae, Haptophyta). Protist 157:213-234

Young J, Henriksen K (2003) Mineralization within vesicles: the calcite of coccoliths. Rev Mineral Geochem 54:189-215

Zeebe, RE; Westbroek, P (2003) A simple model for the $\mathrm{CaCO}_{3}$ saturation state of the ocean: The "Strangelove", the "Neritan", and the "Cretan" ocean. Geochem Geophy Geosystems doi: 10.1029/2003GC000538

Zhuravlev AYu, Wood RA (2008) Eve of Biomineralization: controls on skeletal mineralogy. Geology 36:923-926

Zlatogursky VV (2012) Raphidiophrys heterophryoidea sp nov (Centrohelida:

Raphidiophryidae), the first heliozoan species with a combination of siliceous and organic skeletal elements. Eur J Protistol 48:9-16 


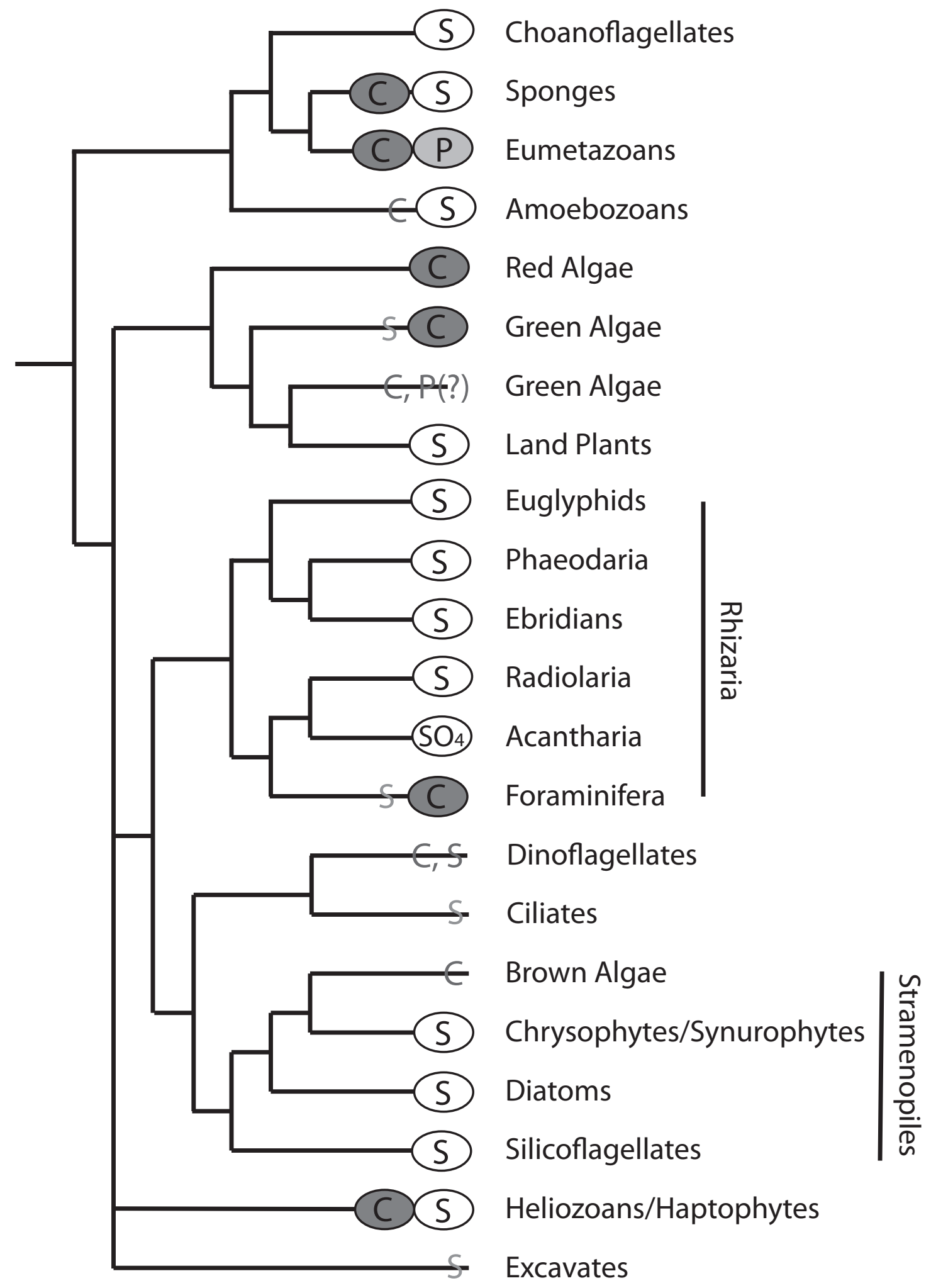




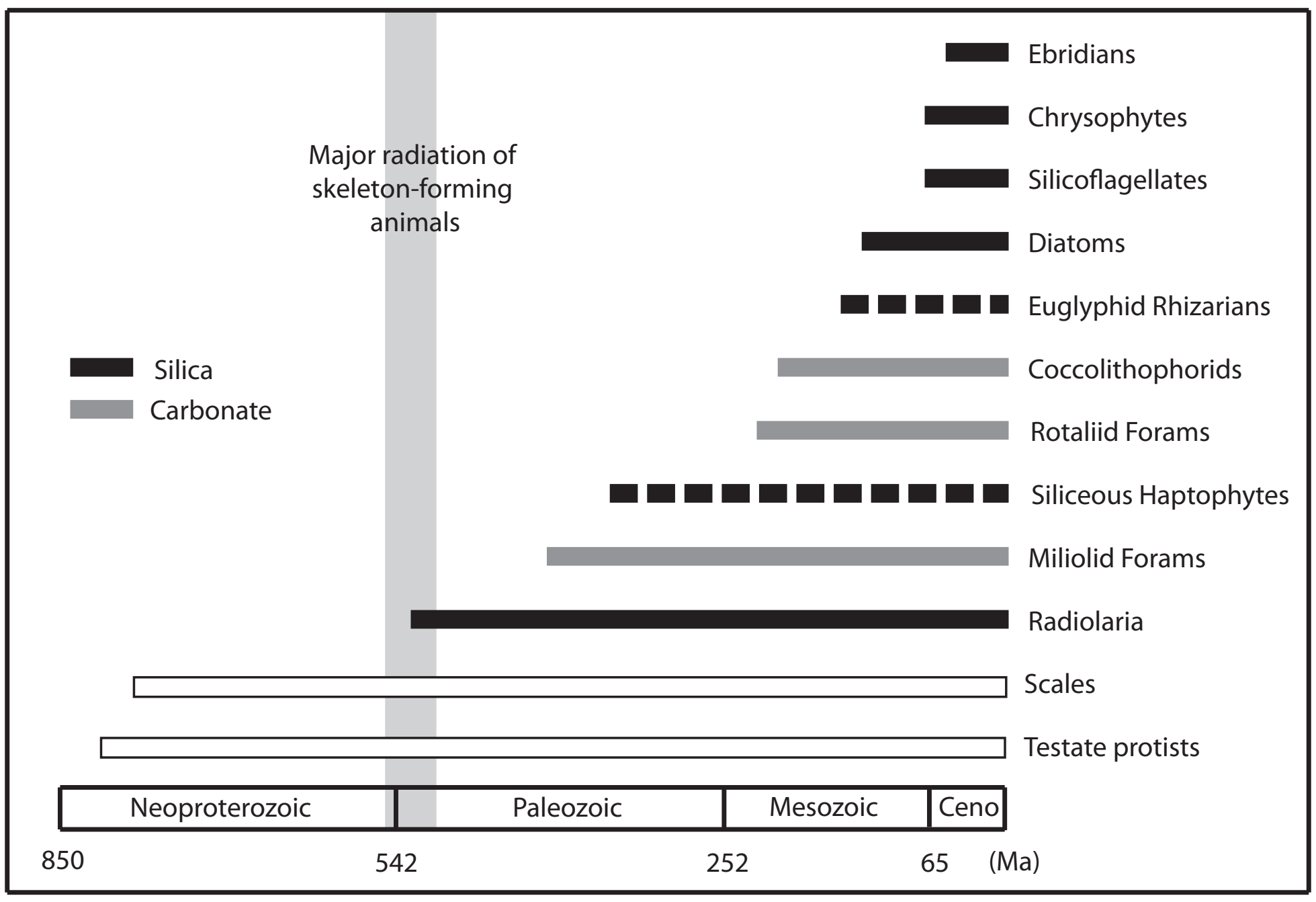

